\title{
PENINGKATAN KUALITAS PENDIDIKAN ANAK USIA DINI MELALUI PENYEDIAAN SARANA PENUNJANG PROSES PEMBELAJARAN PADA POS PAUD DI KELURAHAN MERJOSARI MALANG
}

\author{
Rahayu Puji Suci, Suhermin, Triyonowati \\ Email : poppedot87@gmail.com \\ Magister Manajemen PPS Universitas Widyagama Malang \\ STIESIA Surabaya
}

\begin{abstract}
Abstrak: Program pendidikan anak usia dini di Kota Malang masih kurang merata. Tim Pelaksana memberikan solusi alternatif terhadap beberapa permasalahan yang dihadapi oleh dua Pos PAUD yaitu Pos PAUD "ASPARAGA dan Pos PAUD "JAYA KUSUMA yang terletak di wilayah Kelurahan Merjosari Malang. Letak Pos PAUD Pos PAUD “ASPARAGA dan Pos PAUD "JAYA KUSUMA meski ada di wilayah Kota Malang, namun posisi berada di pinggiran Kota Malang. Skala prioritas yang menjadi sasaran Tim untuk solusi atas permasalahan kedua Pos PAUD adalah 1. Menghasilkan alat peraga edukatif (APE) dalam/indoor dan APE luar/outdoor. 2. Menghasilkan penunjang proses belajar mengajar yang berupa meja dan kursi siswa sebagai sarana yang nyaman dalam proses pembelajaran Pos PAUD. 3.Menghasilkan Pelatihan parenting berbasis pembelajaran berkulaitas pada anak usia dini. Hasil implementasi instrumen tersebut adalah: a) Pos PAUD yang dihasilkan menjadi lebih berkualitas, b). Lebih efisien tempat, waktu, tenaga dan biaya dalam pengelolaan Pos PAUD, c). Tatakelola manajemen maksimal, terprogram, terdata dengan baik dan benar
\end{abstract}

Kata Kunci: pos paud, alat peraga edukatif (ape), sarana pembelajaran, planning, organizing, actuating, dan controlling (poac).

Abstract: Early childhood education programs in the city of Malang is still uneven. Executive Team provide alternative solutions to some of the problems faced by the two, namely Pos Paud "ASPARAGA and Pos Paud" JAYA KUSUMA located in the Village area Merjosari Malang. Pos layout Pos Paud "ASPARAGA and Pos Paud " KUSUMA JAYA although there are in the city of Malang, but the position is located on the outskirts of the city of Malang. Priorities are being targeted for Team Pos solutions for problems of both Pos Paud is 1 . Produce educational props (APE) in / indoor and outdoor APE / outdoor. 2. Generate support teaching and learning process in the form of tables and chairs as a convenient means of students in the learning process early childhood Pos. Training 3.Menghasilkan parenting berkulaitas-based learning in early childhood. The results of the implementation of such instruments are: a) Pos Paud resulting into better quality, b). More efficient place, time, effort and money in the management of early childhood Pos, c). Governance maximum management, programmed, recorded properly and correctly.

Keywords: post early childhood, educational props (ape), a means of learning, planning, organizing, actuating, and controlling (POAC)

\section{PENDAHULUAN}

Di dalam pasal 28 Undang-Undang Republik Indonesia Nomor 20 tahun 2003 bahwa POS PAUD adalah suatu upaya pembinaan yang ditujukan kepada anak sejak lahir sampai dengan usia enam tahun yang dilakukan melalui pemberian rangsangan pendidikan untuk membantu pertumbuhan dan perkembangan jasmani dan rohani agar anak memiliki kesiapan dalam memasuki pendidikan lebih lanjut.
Dengan amanat undang-undang mengenai implementasi pengembangan pendidikan anak usia dini, tentu harus disertai dengan sebuah kerangka kebijakan yang khusus mengatur tentang pendidikan anak usia dini. Untuk mendukung perluasan layanan harus ditunjang dengan ketersediaan satuan POS PAUD yang mudah diakses, ketersediaan pendidik sesuai dengan kompetensi yang diharapkan, partisipasi masyarakat dalam peningkatan kualitas pen- 
didikan anak usia dini, dan dukungan penyelenggaraan POS PAUD baik dari Pusat, Daerah, serta masyarakat.

Permasalahan tentang penyeleng-garan POS PAUD juga terjadi di Kota Malang. Semua dilakukan sebagai upaya pemerataan pendidikan yang bermutu pada semua jenjang Sehingga diperlukan adanya sebuah bentuk kolaborasi atau kerjasama antar lembaga, baik itu lembaga daerah, swasta maupun masyarakat.

Penyelenggaraan POS PAUD yang seharusnya berada di bawah dinas pendidikan, berpindah menjadi sebuah kepengurusan pada PKK Kota Malang yang merupakan representasi program kerja Ibu Walikota Malang. Menanggapi sebuah ironi pendidikan yang terjadi memang permasalahan akan selalu muncul apabila antara penyelenggara pendi-dikan dengan pemerintah Kota Malang sendiri tidak dapat menciptakan sebuah pelayanan yang prima.

Sementara POS PAUD menjadi hal yang dipandang modern bagi masyarakat tingkat ekonomi bawah karena dengan biaya yang murah mereka bisa menyekolahkan anaknya. Dapat dilihat bahwa pelaksanaan program pendidikan anak usia dini di Kota Malang masih kurang merata dikarenakan pemerintah tidak dapat menciptakan pelayanan prima sebagai wujud dari kewajiban daerah pada umumnya

Tim mengindentifikasi perma-salahan, lebih lanjut Tim memberikan solusi alternatif terhadap beberapa permasalahan yang dihadapi oleh dua Pos PAUD pinggiran di kelurahan Merjosari Malang. Letak kedua Pos PAUD meski ada di wilayah Kota Malang, namun posisi berada di pinggiran Kota Malang. Mengupayakan untuk, bagaimana agar kedua Pos Paud di kelurahan Merjosari Malang dapat berkembang, berkualitas dan mampu bersaing dengan Kelompok Pos PAUD yang sudah terlebih dahulu berdiri serta berkembang, sehingga mampu pula bersaing dengan PAUD swasta.

Berdasarkan hasil survey yang dilakukan oleh Tim, Pos PAUD Pinggiran Di Kelurahan Merjosari Kota Malang dapat dijelaskan sebagai berikut:

1) Kelompok Pos PAUD "ASPARAGA"

a) Kepala Pengelola: Qurrotul A'yuni, S.Pd

b) Alamat: J1. Joyo Tamansari I RT 05 RW 06 Kelurahan Merjosari Keca-matan Lowokwaru Kota Malang.

2) Kelompok Pos PAUD "JAYA KUSUMA"

a) Kepala Pengelola: Dra Riana Triwulandari

b) Alamat: Jl. Joyo Asri Blok 7 nomor 91 RT.05/RW.08 Kelurahan Merjo-sari, Kec Lowokwaru, Kota Malang.

\section{Permasalahan}

Kedua Pos PAUD dalam menjalan-kan langkah-langkah kegiatan pembelajaran meliputi, proses pembentukan, pengelolaan, pelaksanaan, evaluasi dan pembinaan. Kondisi riil masih diemukan beberapa kendala dalam mewujudkan Pos PAUD yang relatif ideal, murah dan kualitas bersaing. Berikut ini beberapa kendala yang dihadapi:

1. Pada tahap proses pembentukan Pos PAUD, kendala yang ditemukan adalah keterbatasan tempat untuk kegiatan Pos PAUD. Syarat-syarat tersedianya sanitasi dasar, ruangan yang cukup untuk melaksanakan kegiatan, halaman yang luas dan finansial. Selain masalah tempat, masih kekurangan fasilitas untuk sarana penyampaian materi pelajaran yang berbentuk alat peraga edukatif/APE indoor/beberapa macam sentra maupun APE outdoor, yang diharapkan akan mampu meningkatkan kualitas dan kompetensi siswa Pos PAUD. Adapun kekurangan alat peraga edukatif/APE indoor/beberapa sentra maupun APE outdoor, dampaknya tidak hanya pada 
peserta didik, tapi juga kepada dorang tua terkait kurangnya daya tarik mereka ketika akan mendaftarkan anaknya ke Pos PAUD.

2. Pada tahap penyelenggaraan Pos PAUD kendala yang dihadapi, antara lain tidak adanya rencana kegiatan yang jelas, karena keterbatasan sarana alat penunjang untuk pembuatan rencana rencana sebagai perwujutan dalam implementasi proses belajar mengajar

3. Pada tahap proses pelaksanaan kegiatan, pengelola atau penyelenggara Pos PAUD menghadapi kendala keter-batasan tempat, sehingga menghambat pembagian kelompok secara umur apabila peserta didik Pos PAUD sudah banyak, maka diperlukan tempat yang luas untuk membagi anak menjadi 2 atau 3 kelas agar pengajarannya lebih optimal. Demikian kendala untuk kenyamanan belajar yaitu meja dan kursi untuk duduk dalam posisi belajar siswa usia dini tidak ada.

4. Pada tahap evaluasi dan pembinaan, tidak ada evaluasi program yang fokus terhadap Pos PAUD, pengawasan oleh yang berwewenang tidak secara periodik dan dalam melakukan evaluasi terkesan sepihak. Sehingga pengelola atau penyelenggara Pos PAUD kurang mengerti langkah-langkah apa yang harus diambil agar Pos PAUDnya terus berkembang. Kadangkala Pos PAUD tidak melakukan pelaporan perkem-bangan anak dan program. Kemungkinan, kurang mengetahui cara pembuatan dan penyampaian laporan tersebut sehingga pendampingan dan pembenahan manajemen Pos PAUD berbasis Planning, Organizing, Actuating, dan Controlling (POAC) perlu dilakukan

Pada dasarnya permasalahan yang dihadapi kedua Pos Paud sangat beragam dan saling terkait antara permasalahan yang satu dengan lainnya. Namun demikian untuk mempermudah solusi, maka permasalahan dikelompokkan menjadi dua aspek utama yaitu permasalahan fasilitas sarana prasarana dan permasalahan manajemen.

\section{Permasalahan Fasilitas Sarana dan Prasarana Pembelajaran}

Walaupun dari hasil analisis situasi kedua Pos Paud mempunyai kondisi yang sedikit berbeda, namun setelah ditelaah lebih seksama maka secara garis besar permasalahannya yang terjadi hampir sama. Permasalahan fasilitas terdiri dari :

1) Masalah kurangnya fasilitas bermain siswa yang berbentuk alat peraga edukatif/APE. Dengan alat peraga edukatif yang terstandart diharapkan akan meningkatkan kualitas pendidikan maupun kemampuan siswa menjadi lebih optimal. Kondisi Pos PAUD ASPARAGA maupun Pos PAUD JAYA KUSUMA menunjukkan bahwa masih diperlukan APE dalam/indoor beberapa macam sentra (sentra matematika, sentra balok, sentra bahasa), APE luar/outdoor.

2) Masalah masih belum mempunyai penunjang proses belajar mengajar yang berupa, lemari untuk arsip administrasi, loker tempat untuk kerapian mainan, meja kursi guru, komputer sebagai sarana membuat administrasi, meja dan kursi siswa. Siswa yang selama ini duduk di lantai yang beralaskan karpet.

\section{Permasalahan Manajemen}

1) Masih menggunakan sistem promosi sederhana dengan selebaran yang terbatas guna menginformasikan dan menawarkan Pos PAUD ke warga RW setempat dan ke wilayah RW lain maupun masyarakat wilayah sekitar.

2) Masalah manajemen mutu pembelajaran kedua Pos PAUD belum adanya kendali 
kualitas. Belum adanya evaluasi program yang fokus pengembangan dan pelaksanaan Pos PAUD, sehingga pengelola atau penyelenggara Pos PAUD kurang mengerti langkah-langkah apa yang harus diambil agar Pos PAUD-nya berkembang mencapai kualitas yang optimal.

3) Belum dilakukan pengarsipan yang tertib dan rapi, tatakelola administrasi belum benar, tatakelola keuangan per periode perlu pembenahan.

\section{METODE PELAKSANAAN}

\section{Solusi Yang Ditawarkan}

\section{A. Masalah Fasilitas Sarana dan Prasarana}

1) Diperlukan penambahan untuk alat bermain siswa Pos PAUD maka solusinya adalah dengan menambah alat yang mampu mempercepat peningkatan kualitas pendidikan dalam proses belajar mengajar siswa. Untuk itu maka didesain dan dibuat Alat Peraga Edukatif (APE) indoor berupa sentra balok, sains-matematika, sentra bahasa dan dan APE outdoor berupa desain alat peraga motorik plurutan, ayunan, titian.

2) Menghasilkan penunjang proses belajar mengajar yang berupa desain meja dan kursi siswa sebagai sarana untuk perbaikan proses pembelajaran Pos PAUD, sehingga tidak belajar di lantai yang beralaskan karpet, pembelajaran menjadi tidak terkendala, pembelajaran menjadi nyaman.

\section{B. Masalah Manajemen}

1) Masalah sistem promosi konvensional dari mulut ke mulut bisa diselesaikan dengan membuat informasi tentang Pos PAUD yang mudah diakses oleh masyarakat. Untuk itu dengan mendesain brosur yang komunikatif dan memberikan alamat pada brosur, setting redaksional brosur yang komunikatif agar lebih tersosialisasi dan lebih jelas dalam informasikan Pos Paud.
Dengan demikian maka masyarakat RW setempat dapat melihat dan mengikuti perkembangan Pos PAUD, terinformasikan tentang biaya/SPP, lebih cepat dan akurat untuk mendapatkan informasi terkait Pos PAUD.

2) Masalah manajemen mutu pembelajaran kedua mitra Pos PAUD belum adanya kendali kualitas. Pendekatan yang perlu dilakukan untuk menyelesaikan masalah ini adalah solusi pelatihan parenting berbasis pembelajaran berkulaitas pada anak usia dini yang ditujukan untuk pendidik Pos PAUD. Sehingga peningkatan motivasi kualitas kompetensi anak menjadi optimal.

3) Masalah manajemen Pos PAUD. Pendekatan yang perlu dilakukan untuk menyelesaikan masalah ini adalah berbasis Planning, Organizing, Actuating, dan Controlling (POAC)

\section{Rencana Kegiatan}

Rencana kegiatan yang berupa langkahlangkah solusi untuk mengatasi permasalahan baik masalah sarana prasarana dan masalah manajemen Pos PAUD adalah sebagai berikut:

1) Koordinasi dan diskusi antar anggota tim dengan kedua Pos PAUD . Hal ini dimaksudkan untuk mendapatkan masukan dan gagasan yang akan digunakan Tim untuk diimplementasi-kan. Penyamaan persepsi dan langkah gerak dalam pelaksanaan menjadi penting dengan cara kerja yang kolegial seluruh anggota tim dengan kedua Pos PAUD.

2) Merancang pengadaan alat beserta spesifikasinya, dan sekaligus uji coba, yaitu meliputi alat: berupa Alat Peraga Edukatif (APE) indoor berupa sentra balok, sainsmatematika, sentra bahasa dan APE outdoor berupa desain alat peraga motorik plurutan, ayunan, titian. 
3) Merencanakan dan mengkonsep materi yang dibutuhkan untuk Pelatihan manajemen kendali mutu terfokus tentang parenting berbasis pembelajaran berkulaitas pada anak usia dini yang ditujukan untuk guru Pos PAUD, pelatihan manajemen organi-sasi Pos PAUD berbasis Planning, Organizing, Actuating, dan Controlling (POAC)

\section{Partisipasi kedua Pos PAUD}

1) Kedua Pos PAUD turut serta dalam diskusi untuk memberikan informasi tentang berbagai persoalan dan menyampaikan kesulitan yang dihadapi terkait sentra alat peraga edukatif, penunjang proses belajar mengajar yang berupa meja dan kursi siswa, pengelolaan manajemen organisasi Pos Paud, sehingga luaran yang dihasilkan program ini benarbenar bermanfaat dan sesuai dengan harapan.

2) Ikut menyiapkan sarana dan prasarana dalam uji coba alat yang telah dihasilkan bersama dengan anggota tim. Mengikuti pelatihan dan tutorial sehingga mengetahui bagaimana implementasikan maneje-men organisasi Pos PAUD dengan benar.

3) Bersedia bekerja sama dengan Tim secara berkelanjutan bilamana diperlukan.

\section{HASIL DAN PEMBAHASAN}

Salah satu Kelurahan di Wilayah Kecamatan Lowokwaru kota Malang adalah kelurahan Merjosari. Kelurahan Merjosari jaraknya kurang lebih 15 kilometer dari pusat kota, memiliki 12 RW yang tersebar. Meski Kelurahan Merjosari kategori masuk wilayah Kotamadya, namun letak wilayah berada di ujung paling barat, perbatasan dengan kecamatan Sengkaling Kabupaten Malang. Ironisnya masih terdapat penduduk taraf pendidikan rendah. Hal terkait berdampak pula pada keterbatasan kemampuan untuk sekolahkan anak usia dini mereka pada Playgroup / PAUD swasta yang cenderung komersial secara riil dengan biaya yang relatif tinggi.

Dari sebaran wilayah yang meliputi 12 RW tersebut, di kelurahan Merjosari terindentifikasi ada 7 Pos PAUD (Pos Pendidikan Anak Usia Dini). Pos PAUD adalah program layanan pendidikan yang penyelenggaraannya adalah non formal, diintegrasikan dengan program Bina Keluarga Balita (BKB) dan Posyandu balita, menjadi satu kesatuan. Pos PAUD ditujukan utamanya bagi masyarakat tidak mampu untuk mengikutsertakan anaknya dalam layanan PAUD. Satuan seperti Pos PAUD, sejenis bentuk lain yang sederajat dengan PAUD. Bedanya, PAUD sifatnya lebih intensif, relatif komersial/profit oriented, sifat penyelenggaraannya adalah formal.

Hadirnya Pos PAUD di wilayah Kelurahan Merjosari, ternyata memberi dampak yang positif bagi masyarakat tidak mampu tingkat ekonomi bawah. Masyarakat merasa terbantu dalam mengasuh dan mendidik tumbuh kembang anak-anaknya. Di lain hal UU Sisdiknas No. 20 Tahun 2003 disebutkan bentuk Pos PAUD, yang mengcover layanan PAUD diintegrasikan dengan program Bina Keluarga Balita (BKB) dan posyandu balita. Peran Pos PAUD, signifikan dalam masyarakat, karena dikelola dengan prinsip "dari, oleh dan untuk masyarakat", dibentuk atas kesepakatan masyarakat dan dikelola berdasarkan azaz gotong royong, kerelaan, dan kebersamaan, sangat berpotensi dapat berkembang menjadi PAUD, akan tetapi perkembangan ini mungkin luput dari stakeholder yang terkait. Setelah terbentuknya Pos PAUD langkah lebih lanjut, layaknya harus diperhatikan perkembangannya, hal ini perlu dilaksanakan agar membantu pendataan dan mengurangi disparitas layanan 
Pos PAUD antara daerah perkotaan, daerah pinggiran kota dan daerah pedesaan.

Pos PAUD wilayah RW di kelurahan Merjosari, berupaya melaksana-kan prinsip dasar yang terstandart. Namun prakteknya masih menemui banyak kendala, salah satu penyebabnya adalah: 1) keterbatasan penunjang sarana pendidikan (minimnya alat peraga edukatif/APE indoor berupa berbagai macam sentra, APE outdoor, tidak adanya meja kursi siswa maupun meja kursi guru), 2) Optimalisasi kualitas belum maksimal. 3) rendahnya tatakelola adimistrasi Pos PAUD dan administrasi keuangan. Oleh karena itu, perlu adanya sebuah strategi mengoptimal-kan kerja sama semua lini agar Pos PAUD pinggiran di wilayah Kelurahan Merjosari, memiliki kompetensi standart dan dapat bersaing dengan PAUD swasta yang orientasi sepenuhnya profit.

Satu sisi pendidikan anak usia dini adalah urgen. Sisi lain sayangnya sampai saat ini posisi Pos PAUD di Merjosari masih terasa termajinalkan apabila dibanding dengan PAUD yang bukan dari rintisan BKB maupun Posyandu. Alasannya antara lain adalah fasilitas yang dimiliki oleh Pos PAUD kurang lengkap, tenaga pendidik kurang kompeten dan tempat yang kurang memadai. Kendala-kendala inilah banyak dijumpai di berbagai daerah yang terdapat Pos PAUD termasuk di Pos PAUD wilayah pinggiran kota Malang seperti pada Wilayah kelurahan Merjosari. Pos PAUD masih kalah bersaing dengan PAUD swasta yang ada. Disisi lain meskipun SPP per siswa rata rata dalam hitungan nominal dibawah standar atau sangat minim untuk pembayaran per bulannya dan kondisi pendidik/guru tidak dibayar, namun tetap berupaya bagaimana Pos PAUD dengan prinsip mudah, murah dan bermutu dapat bersaing dengan PAUD swasta.

Sampai saat ini upaya untuk melaksanakan program Pos PAUD antara lain ikutsertakan kader dalam pelatihan baik yang diselenggarakan oleh Tim Penggerak PKK Kota Malang maupun Provinsi. Adapun data terakhir kedua Pos PAUD , pada Gambar 1, dimana pengurus dan pendamping masih kesulitan dalam mengembangkan manajemen Pos PAUD kearah yang lebih kreatif. Hal terkait disebabkan fenomena keterbatasan penunjang kegiatan pendidikan (APE Indoor berupa berbagai sentra sangat kurang, APE outdoor untuk motorik siswa, belum adanya meja kursi siswa, meja kursi guru, lemari penyimpan arsip siswa, loker tempat mainan dan penunjang administrasi masih sangat minim. Gambar 2 menunjukkan kedua Pos PAUD memaksimalkan tempat proses belajar mengajar yang merupakan swadaya masyarakat, tempat dan fasilitas yang minim dalam menjalankan aktivitas kegiatan, namun tetap berupaya maksimal menyesesuaikan kurikulum dan panduan Pos PAUD yang ada.

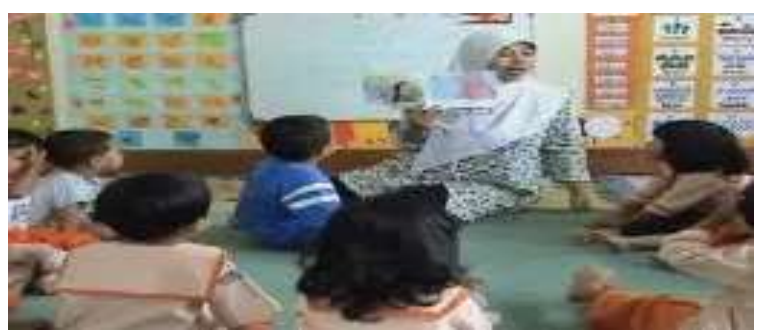

Gambar 1. Keterbatasan Penunjang Kegiatan

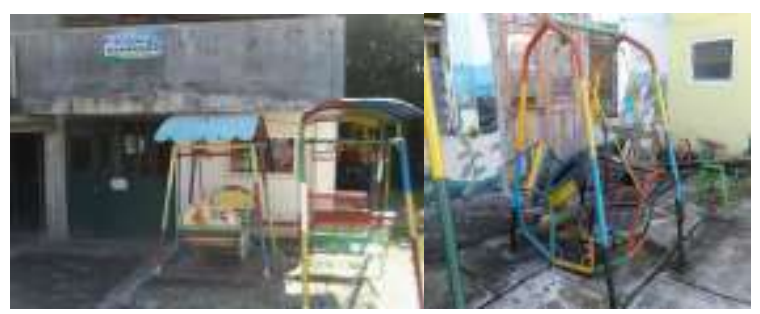

Gambar 2. Lokasi/Tempat Pos PAUD dan Fasilitas Yang Minim

\section{Kegiatan Pos PAUD}

Kedua Pos PAUD di Keluarahan Merjosari Malang, berfungsi memberikan 
pendidikan sejak dini \& membantu meletakkan dasar ke arah pengembangan sikap, perilaku, perasaan, kecerdasan, sosial \& fisik yg diperlukan dlm menyesuaikan diri dengan lingkungan yang berpengaruh terhadap tumbuh kembang anak usia dini. Gambar 3 dan Gambar 4 adalah lokasi dan bagian dari kegiatan kedua Pos PAUD yaitu Pos PAUD "ASPARAGA" dan Pos PAUD "JAYA KUSUMA".

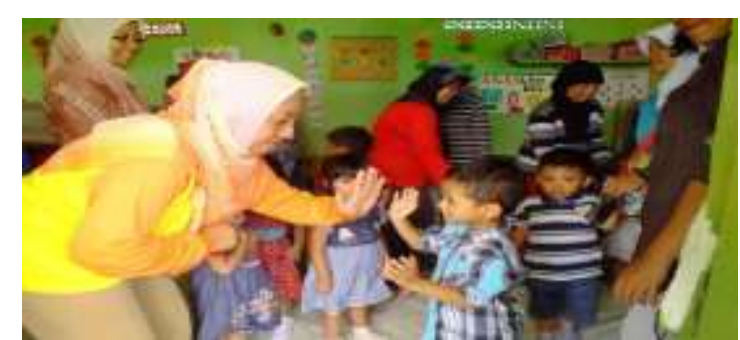

Gambar 3. Kegiatan Pos PAUD "JAYA KUSUMA"

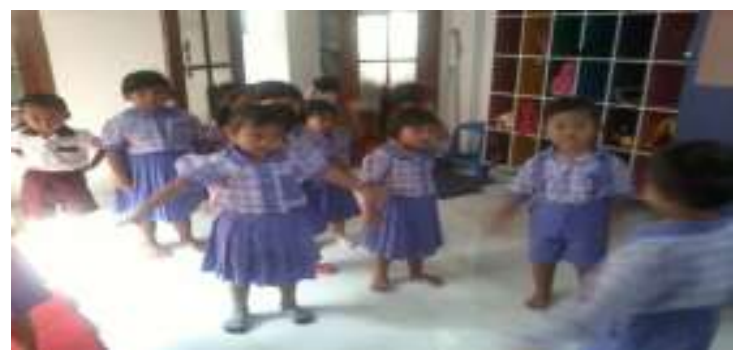

Gambar 4. Kegiatan Pos PAUD "ASPARAGA"

Kegiatan Kedua Pos PAUD di Keluarahan Merjosari Malang, bidang pengembangan yang berkaitan adalah: 1) Kesehatan, dimana sumber daya manusia yang berkualitas sejak awal merupakan modal dasar bagi proses tumbuh kembang anak untuk selanjutnya. Pertumbuhan anak ditandai dengan adanya peningkatan tinggi badan, berat badan, dan lingkar kepala. 2) Psikososial yang mana berfungsi mengoptimalkan tumbuh kembang anak.

Gambar.5 dan Gambar.6 adalah BKB ( Bina Keluarga Balita) yang merupakan bagian dari kegiatan Kedua Pos PAUD di Keluarahan Merjosari Malang.

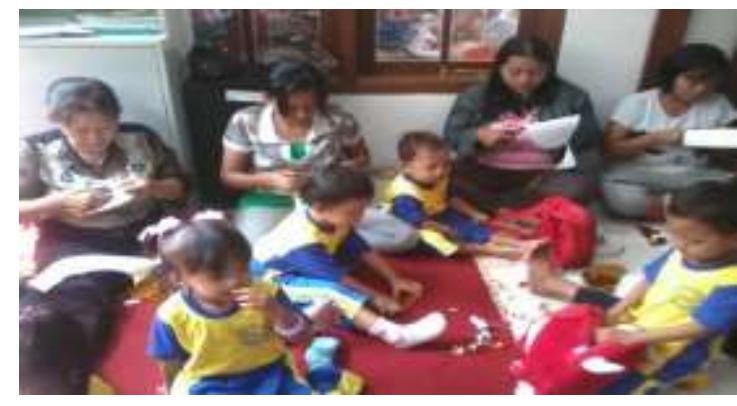

Gambar 5. BKB ASPARAGA,

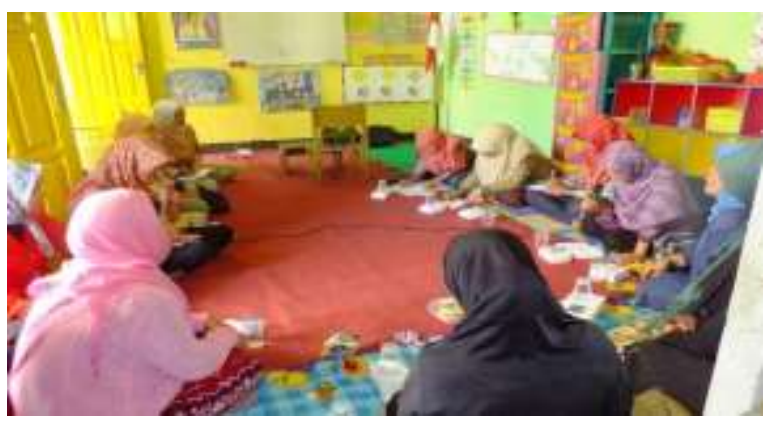

Gambar 6. BKB JAYA KUSUMA

\section{Potensi dan Peluang Pos PAUD}

Potensi dan peluang kedua Pos PAUD ini sangat prospektif. Setiap tahunnya teridentifikasi warga setempat dan wilayah terdekat antusias memasukkan anak usia dini mereka masuk Pos PAUD. Hal ini dikarenakan kebutuhan untuk meningkatkan pendidikan anaknya. Disisi lain Pos PAUD setiap tahunnya juga selalu membutuhkan siswa baru. Selain itu, kelengkapan kegiatan Bina Keluarga Balita yang merupakan muatan ilmu pengasuhan dan tumbuh kembang anak untuk para ibu/orangtua siswa Pos PAUD menjadi andalan dan nilai tambah . serta daya tarik. BKB berisi kegiatan-kegiatan positif untuk pengetahuan kesehatan gizi anak, pengasuhan anak, dan lainnya. Sementara itu, kebutuhan Pos PAUD masih belum bisa dipenuhi terkait sentuhan inovasi, sarana prasarana untuk kreatif anak dan kreatifitas ibu sebagai orang tua siswa. Sehingga pengetahuan para anak dan ibu, layaknya selalu terus diupayakan untuk mengikuti perkembangan pendidikan di era saat ini/era globalisasi. 
Fakta menunjukkan bahwa saat ini jumlah Pos PAUD terus berkembang proporsional dengan perkembangan BKB, sampai masuk ke wilayah pedesaan. Hampir setiap daerah di wilayah Malang juga sudah terdapat Pos PAUD. Maka untuk perkembangan Pos PAUD menjadi sangat potensial, berprospek positif utamanya untuk mengangkat dan meningkatkan taraf pendidikan usia dini bagi masyarakat kurang mampu dan bisa dikembangkan sebagai wahana pendidikan yang mempunyai peluang cukup bagus pada dunia pendidikan usia dini.

\section{Kelembagaan Kedua Pos PAUD}

Sebagaimana Pos PAUD pada umunya, Pos PAUD ASPARAGA maupun JAYA KUSUMA sudah ada kelembagaan yang tetap, tetapi banyak kekurangan manajemen, tatakelola administrasi dan minimnya fasilitas penunjang proses belajar mengajar, karena sebagaian besar pengelola Pos PAUD adalah pengelola yang tidak ada kontribusi tetap / tidak digaji / tidak dibayar, merupakan sukarelawan pendidik anak usia dini, sebagai tenaga pengabdi masyarakat. Di lain hal keberadaan Pos PAUD, pengelolaan sampai saat ini adalah swadaya. SPP siswa per bulan masih kategori dibawah standar. SPP dipakai antara lain untuk operasional biaya Pos PAUD. Sayangnya bentuk kelompok Pos PAUD, belum mendapatkan perhatian yang serius dari pemerintah untuk dikembangkan yang lebih dapat berkompetisi.

\section{Implementasi APE Luar/Outdoor}

Alat Permainan Edukatif (APE) adalah alat permainan yang dapat mengoptimalkan kualitas perkembangan anak, disesuaikan dengan kelompok usia anak atau standar tingkat pencapaian perkembangan anak. APE Luar/Outdoor adalah sarana bermain anak usia dini yang biasanya ditempatkan di luar ruangan atau di halaman sekolah. Tujuannya agar anak memiliki keleluasaan dalam bergerak, bermain menggunakan alat permainan ini.

Diantara mainan anak-anak edukatif adalah panjat tali, manfaat bermain bagi anak adalah mengajarkan anak belajar:

a) Kendali tubuh karena yang menggerakkan bukan hanya dorongan orang lain, tapi juga dari gerakan tubuh ke depan dan ke belakang.

b) Keseimbangan, belajar menemukan titik keseimbangan tubuhnya agar dia tidak jatuh.

c) Konsep cepat dan lambat. Balita belajar bergerak motoric semakin cepat.

Spesifikasi bahan adalah rangka pipa bulat 2, rangka kursi pipa bulat 1 Kemudian, mainan anak-anak Edukatif lainnya adalah sluncur. Seluncur atau yang biasa disebut dengan plurutan ini biasa digunakan pada taman kanakkanak atau Paud. Berfungsi untuk melatih keberanian dan ketangkasan siswa.

Perosotan dengan warna yang menarik, siswa tidak akan merasa canggung ataupun takut. Perosotan terbuat dari bahan fiber glass dan besi dengan panjang 2,5 meter, pada Gambar 7. Manfaat bermain plurutan adalah bahwa anak dapat belajar:

a) Berani menghadapi ketinggian karena dia harus meluncur dari tempat yang tinggi.

b) Keseimbangan, saat anak menaiki tangga dan meluncur dari perosotan. Anak harus bisa menjaga keseimbangan tubuhnya agar tidak terguling dan bisa sampai di ujung bawah perosotan dengan posisi tetap duduk tegak.

c) Sabar mengantre mendapatkan giliran untuk merosot. Perosotan harus dimainkan secara bergantian untuk menghindari tabrakan dengan anak lain, bila suasananya ramai. Ajarkan anak untuk menunggu agar anak lain yang meluncur sampai di bawah lebih dulu, sebelum giliran anak Anda. 
d) Berbagi karena mainan perosotan adalah mainan yang bisa dimainkan beramai-ramai. Anak harus mau berbagi dengan anak-anak lain yang juga ingin ikut bermain.

Selanjutnya, salah satu media permainan untuk melatih keseimbangan adalah junkat jungkit warna warni, terlihat pada Gambar 8 . Wahana ini berfungsi melatih mental keberanian anak dan melatih otot motorik serta keseimbangan badan. Wahana ini mempunya panjang 2 meter, lebar titian $15 \mathrm{~cm}$, dan tinggi $30 \mathrm{~cm}$.

Papan titian (Balance Beam Axerciser) sangat berfungsi untuk melatih keseimbangan dalam berdiri, berjalan dan meniti, melatih keberanian dan kepercayaan diri, konsep tinggi rendah juga melatih koordinasi mata, kaki dan koordinasi ruang. Latihan berjalan diatas papan titian menguatkan bagian otot kaki Tibialis Anterior yang berperan penting saat anak berlari dan melompat, serta koordinasi antara mata dengan kaki. Adapun tujuannya adalah:

a) Melatih kekuatan otot kaki.

b) Melatih keseimbangan tubuh.

c) Melatih menggerakan badan dan kaki untuk kekuatan otot dan koordinasi.

d) Melatih keberanian dan kepercayaan diri.

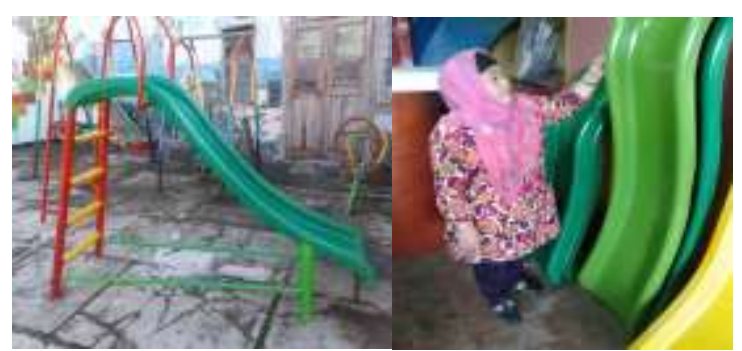

Gambar 7. Plurutan Anak

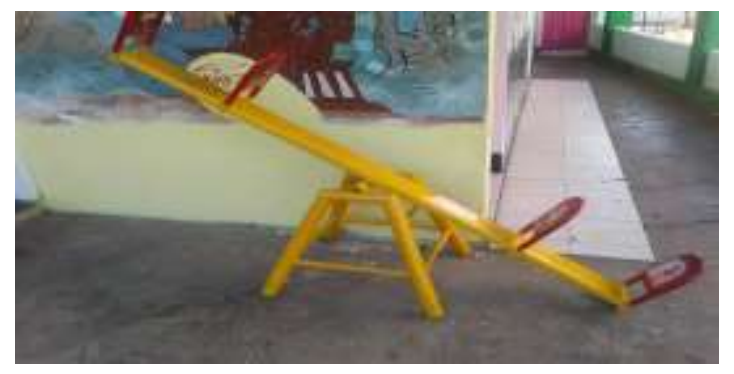

Gambar 8. Jungkat jungkit warna warni 60

\section{Implementasi APE Dalam / Indoor}

Alat permainan edukatif (APE) pada kedua Pos Paud adalah permainan yang dirancang secara khusus untuk kepentingan pendidikan. APE untuk anak Pos Paud adalah alat permainan yang dirancang untuk tujuan meningkatkan aspek-aspek perkembangan anak usia dini. Permainan edukatif merupakan semua bentuk permainan yang dirancang untuk memberikan pengalaman pendidikan atau pengalaman belajar kepada anak usia dini, termasuk permainan tradisional dan moderen yang diberi muatan pendidikan dan pengajaran. Atas dasar pengertian itu, permainan yang dirancang untuk memberi informasi atau menanamkan sikap tertentu, misalnya untuk memupuk semangat kebersamaan dan kegotongroyongan, termasuk dalam kategori permainan edukatif karena permainan itu memberikan pengalaman belajar kognitif dan afektif.

Alat permainan edukatif (APE) pada kedua Pos Paud, merupakan alat yang dikondisikan untuk digunakan oleh anak bermain sambil belajar artinya alat dan bermain itu sendiri merupakan sarana belajar yang menyenangkan. Anak usia dini pada pos paud tidak akan bosan-bosan bermain, di samping itu dengan bermain akan membawa kepada pengalaman yang positif dalam segala aspek, seperti aspek pengembangan keimanan dan ketakwaan, daya pikir, daya cipta, kemampuan olah tubuh (jasmani). APE dipergunakan sebagai sarana atau peralatan untuk bermain yang mengandung nilai pendidikan edukatif dan dapat merangsang otak pengembangan seluruh aspek kemampuan (potensi) jarak, alat permainan yang sengaja dirancang secara khusus untuk kepentingan pendidikan Disimpulkan bahwa, alat Pendidikan Edukatif, Kreatif dan Inovatif adalah merupakan alat-alat permainan yang dirancang dan dibuat untuk menjadi 
sumber belajar anak-anak usia dini agar mereka mendapatkan pengalaman belajar. Pengalaman ini akan berguna untuk meningkatkan aspekaspek perkembangan anak usia dini seperti aspek fisik/motorik, emosi, sosial, bahasa, kognitif dan moral.

\section{Implementasi Model Pembelajaran dengan Pendekatan Sentra}

Model pembalajaran sentra adalah pendekatan pembelajaran yang dalam proses pembelajarannya dilakukan di dalam "lingkaran" (circle times) dan sentra bermain. Lingkaran adalah saat di mana pendidik duduk bersama anak dengan posisi melingkar untuk memberikan pijakan kepada anak yang dilakukan sebelum dan sesudah bermain.

Pembelajaran yang berpusat pada sentra dilakukan secara tuntas mulai awal kegiatan sampai akhir dan fokus oleh satu kelompok usia Pos PAUD dalam satu sentra kegiatan. Setiap sentra mendukung perkembangan anak dalam tiga jenis bermain yaitu bermain sensorimotor atau fungsional, bermain peran dan bermain konstruktif (membangun pemikiran anak). Macam Sentra Pembelajaran Pada Kedua Pos PAUD yang diimplementasikan antara lain:

\section{Sentra Balok dan Sentra Matematika}

Sentra balok dan matamatika, memfasilitasi anak bermain tentang konsep bentuk, ukuran, keterkaitan bentuk, kerapihan, ketelitian, bahasa, dan kreativitas. Bermain balok selalu dikaitkan dengan main peran mikro, dan bangunan yang dibangun anak digunakan untuk bermain peran. Sentra balok membantu perkembangan anak dalam keterampilan berkonstruksi. Sentra ini terutama untuk mengembangkan kemampuan visual spasial dan matematika anak usia dini.

\section{Sentra Bahasa}

Main peran kecil mengembangkan kemam-puan berpikir abstrak, kemampuan berbahasa, sosialemosional, menyambung-kan pengetahuan yang sudah dimiliki dengan pengetahuan baru dengan 61 menggunakan alat main peran berukuran kecil. Alat dan Bahan Sentra Main Peran Kecil (Mikro): berbagai miniatur mainan, berbagai mainan alat rumah tangga, berbagai mainan mini alat kedokteran, berbagai mainan mini alat transportasi, berbagai mainan mini alat tukang.

\section{Sentra Seni}

Sentra seni dapat dibagi dalam seni musik, seni tari, seni kriya, atau seni pahat. Penentuan sentra seni yang dikembangkan tergantung pada kemampuan satuan Pos PAUD. Disarankan minimal ada dua kegiatan yang dikembangkan di sentra seni yakni seni musik dan seni kriya. Sentra seni mengembangkan kemampuan motorik halus, keselarasan gerak, nada, aspek sosial-emosional dan lainnya.

Adapun tujuan dari pada pem-belajaran sentra dapat disimpulkan sebagai berikut: (a) meningkatkan pelayanan pengalaman belajar kepada anak usia dini secara lebih mendalam dengan memberikan kebebasan bereksplorasi dalam setiap sentranya; (b) dengan adanya sentra melatih anak-anak usia dini untuk lebih mandiri karena tidak bergantung pada guru kelasnya saja, tetapi akan lebih diarahkan untuk melakukan kegiatan dengan guru-guru yang lain terutama yang menjadi guru sentra; (c). dengan adanya guru sentra, maka guru sentra akan lebih fokus dalam mengembangkan sentra yang menjadi tanggung jawabnya dengan menuangkan segala pengembangan ide kreatifnya; (d). proses pembelajaran diharapkan berlang-sung alamiah dalam bentuk kegiatan anak bekerja mengalami, bukan transfer pengetahuan dari guru ke anak; (e) Anak dapat memposisikan sebagai diri sendiri yang memerlukan suatu bekal untuk hidupnya nanti, dalam hal ini guru sentra bertugas sebagai pengarah dan pembimbing atau inspirator.

\section{Pelatihan Konteks Parenting}

Parenting yang diberikan pada kedua Pos Paud, merupakan upaya pendidikan yang 
dilaksanakan oleh keluarga dengan memanfaatkan sumber-sumber yang tersedia dalam keluarga dan lingkungan yang berbentuk kegiatan belajar secara mandiri. Parenting sebagai proses interaksi berkelanjutan antara orang tua dan anak-anak mereka yang meliputi aktivitas-aktivitas sebagai berikut: memberi makan (nourishing), memberi petunjuk (guiding), dan melindungi (protecting) anakanak ketika mereka tumbuh berkembang. Penggunaan kata "parenting" untuk aktivitasaktivitas orang tua dan anak di sini karena memang sampai saat ini belum ada padanan kata dalam bahasa Indonesia yang tepat.

Keluarga sebagai unit sosial terkecil di masyarakat yang terbentuk atas dasar komitment untuk mewujudkan fungsi keluarga khususnya fungsi sosial dan fungsi pendidikan, harus benar-benar dioptimalkan sebagai mitra lembaga PAUD. Oleh karena itu melalui program parenting sebagai wadah komunikasi antar orang tua, disamping untuk memberikan sosialisasi terhadap program-program yang diselenggarakan oleh lembaga PAUD, secara umum tujuan program parenting, adalah mengajak para orang tua untuk bersama-sama memberikan yang terbaik buat anak-anak mereka. Sedangkan secara khusus tujuan pengembangan program parenting adalah: (1) meningkatkan pengetahuan dan keterampilan orang tua dalam melaksanakan perawatan, penga-suhan dan pendidikan anak di dalam keluarga sendiri dengan landasan dasar-dasar kareakter yang baik; (2) memper-temukan kepentingan dan keinginan antara pihak keluarga dan pihak sekolah guna mensikronkan keduanya sehingga pendidikan karakter yang dikembangkan di lembaga Pos PAUD dapat ditindak lanjuti di lingkungan keluarga; (3) menghubung-kan antara program sekolah dengan program rumah. Lembaga Pos PAUD yang memiliki program-program kelembagaan dan pembelajaran kadangkala bertentangan atau tidak selaras dengan kebiasaan-kebiasaan yang terjadi di lingkungan keluarga. Dengan program parenting ini akan terjadi keselarasan dan keterkaitan, kerjasama yang saling mendukung, saling menguatkan.

\section{Pelatihan Konteks Manajemen Untuk Organisasi Pos Paud}

Empat fungsi manajemen yang sering disebut "POAC", yaitu Planning, Organizing, Actuating, dan Controlling, menjadi strategi solusi atas permasalahan pada aspek manajemen.

\section{Fungsi Perencanaan (Planning).}

Implementasi dalam proses, upaya yang dilakukan adalah untuk mengantisipasi kecenderungan di masa yang akan datang dan penentuan strategi serta taktik yang tepat untuk mewujudkan target dan tujuan Kedua Pos Paud di Kelurahan Merjosari Malang. Kegiatan dalam fungsi perencanaan antara lain : menetapkan sasaran, merumuskan strategi untuk mencapai sasaran, menentukan sumber-sumber daya yang diperlukan, menetapkan standar / indikator keberhasilan dalam pencapaian tujuan dan sasaran yang dituju

Strategi dan taktik dalam fungsi perencanaan tersebut diimplementasikan dengan menggunakan metode analisis SWOT (Strength, Weakness, Opportunity and Threat). Implementasikannya dengan perencanaan strategis yang digunakan untuk mengevaluasi kekuatan, kelemahan, peluang, dan ancaman Kedua Pos Paud di Kelurahan Merjosari Malang. Proses ini melibatkan penentuan tujuan yang spesifik, mengidentifikasi faktor internal dan eksternal yang mendukung, maupun yag tidak mendukung, dalam mencapai tujuan Kedua Pos Paud di Kelurahan Merjosari Malang.

2. Fungsi Pengorganisasian (Organizing)

Implementasikan strategi dan taktik dalam sebuah struktur Kedua Pos Paud yang 
tepat dan tangguh, sistem dan lingkungan yang kondusif, dan dapat memastikan bahwa semua pihak dalam Kedua Pos Paud di Kelurahan Merjosari Malang dapat bekerja secara efektif dan efisien guna pencapaian tujuan organisasi. Kegiatan dalam fungsi pengorganisasian antara lain: mengalokasikan sumber daya/sarana, merumuskan dan menetapkan tugas, menetapkan prosedur yang diperlukan, struktur organisasi yang menunjukkan adanya garis kewenangan dan tanggungjawab, sehingga setiap pekerja akan bergerak dan bertindak sesuai dengan job description \& kewenangannya, memiliki tanggung jawab atas pekerjaan yang telah dilaksanakan, kegiatan pelatihan dan pengembangan pendidik Pos Paud. Tersebut di atas, sangatlah penting agar dapat menyegarkan dan menambah wawasan pendidik Pos Paud, kegiatan penempatan Guru Pos Paud pada posisi yang paling tepat .

3. Fungsi Pengarahan Dan Implementasi (Actuating)

Implementasi program agar dapat dijalankan oleh seluruh pihak Kedua Pos Paud di Kelurahan Merjosari Malang serta proses memotivasi agar semua pihak dapat menjalankan tanggungjawabnya dengan penuh kesadaran sehingga produktifitas tinggi. Kegiatan dalam fungsi pengarahan antara lain : mengimplementasikan proses kepemimpinan, pembimbingan, pemberian motivasi kepada tenaga pendidik, anak usia dini agar dapat bekerja secara efektif dan efisien dalam pencapaian tujuan, memberikan tugas dan penjelasan rutin mengenai pekerjaan dan menjelaskan kebijakan yang ditetapkan.

4. Fungsi Pengawasan Dan Pengendalian (Controling)

Implementasi untuk memastikan seluruh rangkaian kegiatan yang telah direncanakan, diorganisasikan dapat berjalan sesuai dengan target yang diharapkan sekalipun berbagai perubahan terjadi. Kegiatan dalam fungsi pengawasan dan pengendalian antara lain : mengevaluasi keberhasilan dalam pencapaian tujuan apakah sudah sesuai dengan indikator yang telah ditetapkan. Hal ini harus secara rutin dilakukan supaya terlihat pada point mana target yang telah tercapai dan target yang belum tercapai sehingga dapat diambil langkah penyelesaian.

Standarisasi Meja dan Kursi Siswa Usia Dini

Meja dan kursi anak merupakan suatu sarana pendukung yang sangat penting dalam kelancaran pelaksanaan proses belajar anak. Dampak dari ketidakserasian antara meja dan kursi dengan ukuran tubuh anak sekolah merupakan salah satu kendala dalam upaya meningkatkan sumber daya manusia yang berkualitas. Akibat dari meja dan kursi sekolah yang tidak sesuai dengan ukuran tubuh anak sekolah antara lain dapat mengakibatkan anak cepat mengalami kelelahan.

Ketidaksesuaian meja dan kursi anak dengan ukuran tubuh anak dapat pula menimbulkan perasaan tidak nyaman (gelisah), kurang konsentrasi, mengantuk, dan lain sebagainya. Apabila kondisi tersebut berlangsung lama (selama masa sekolah), akibat lebih jauh akan menyebabkan perubahan sikap tubuh dan gangguan pertumbuhan. Secara keseluruhan akibatnya akan mengarah kepada gangguan dalam proses belajar.

Mengingat tingkat keaktifan gerak anak yang masih dalam proses pertumbuhan, hal lain yang perlu diperhatikan adalah tingkat keamanan meja dan kursi yang digunakan selama berlangsungnya proses pembelajaran. Gambar 9, meja kursi standar anak usia dini: 

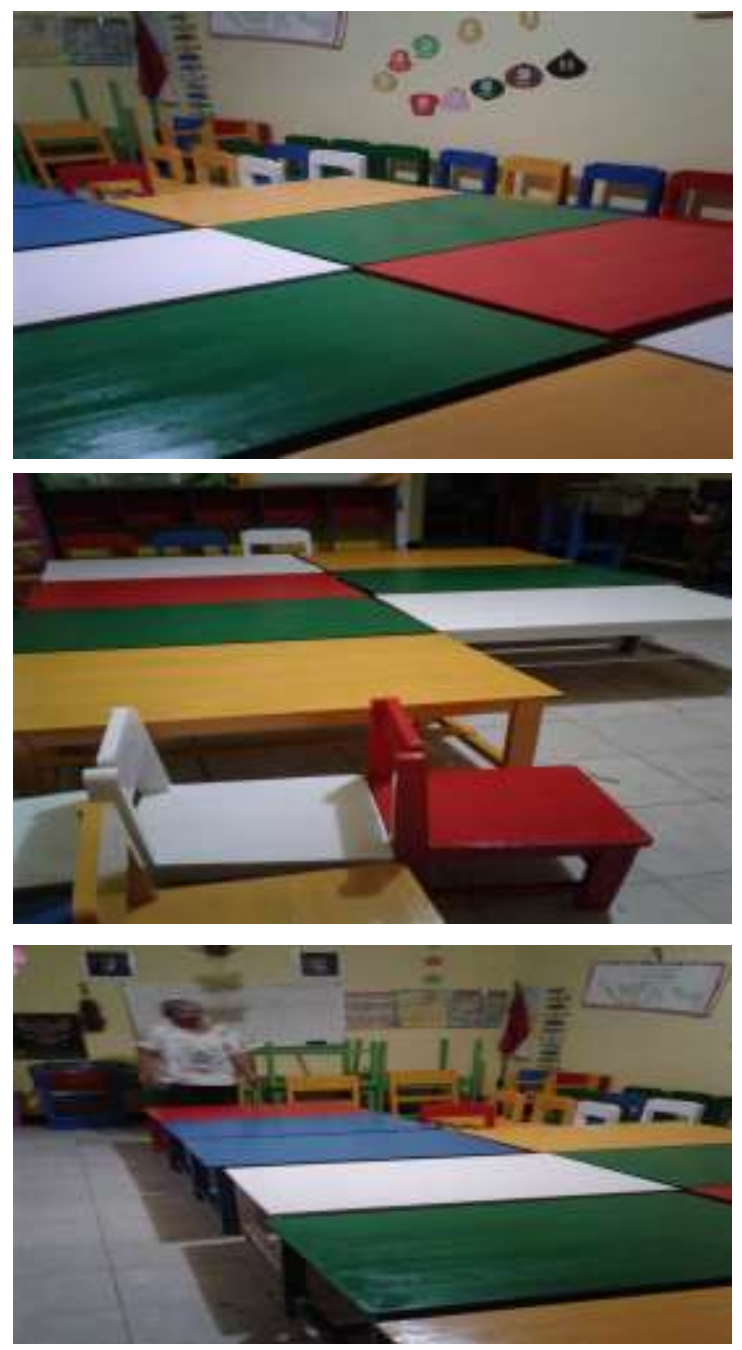

Gambar 9 Meja dan Kursi

\section{KESIMPULAN DAN SARAN \\ Kesimpulan}

1. Sampai saat ini upaya untuk melaksanakan program Pos PAUD pada Kedua Pos Paud di Kelurahan Merjosari Malang antara lain ikutsertakan kader dalam pelatihan baik yang diselenggarakan oleh Tim Penggerak PKK Kota Malang maupun Provinsi.

2. Pos PAUD berfungsi memberikan pendidikan sejak dini \& membantu meletakkan dasar ke arah pengembangan sikap, perilaku, perasaan, kecerdasan, sosial \& fisik yg diperlukan dlm menyesuaikan diri dengan lingkungan yang berpengaruh terhadap tumbuh kembang anak usia dini.
JIP, Vol.7, No. 1, Edisi Januari 2017, Hal: 52-65

Rahayu Puji Suci, Suhermin, Triyonowati

3. Kegiatan pembelajaran di Kedua Pos Paud di Kelurahan Merjosari Malang yang masih seadanya, perbandingan jumlah pendidik dan tenaga kependidikan yang belum sebanding dengan jumlah anak peserta didik sebagaimana yang diharuskan dalam Permendiknas No.58. Tahun 2009 dan juga Petunjuk Teknis Pos PAUD Tahun 2013

4. Silabus / kurikulum Kedua Pos Paud di Kelurahan Merjosari Malang belum memiliki.

5. Keberadaan usia peserta didik rata-rata $3-6$ tahun, namun dalam menggunakan bukubuku administrasi belum maksimal. Hal tersebut perlu adanya pembinaan sehingga, sampai saat ini masih belum mampu mendorong para lembaga Pos PAUD bisa menyelenggarakan pendidikan anak usia dini sebagaimana mestinya.

6. Kesimpulan bahwa kelengkapan dari perencanaan pembelajaran pada kedua Pos PAUD belum maksimal semua jenis perencanaan pembelajaran, begitu pula dengan kesesuaian perencanaan pembelajaran dengan standar yang ada pun belum optimal. Untuk penerapan perencanaan pembelajaran lebih lanjut mutlak dimplementasikan dengan tatakelola yang terkondisi baik.

\section{Saran}

Sebaiknya para ketua dan pendidik di Pos PAUD menyiapkan semua jenis perencanaan pembelajaran yang sesuai dengan standar yang ada dan diterapkan dengan sebaikbaiknya seperti yang telah tertulis dalam Peraturan Menteri Dinas Pendidikan No 58 Tahun 2009 dan juga Petunjuk Teknis Pos PAUD Tahun 2013 sebelum memberikan kegiatan pada anak agar kegiatan yang diberikan pada anak dapat diterima dengan baik dan dapat mencapai tujuan dari Pendidikan Anak Usia Dini (PAUD). 
Pos PAUD mutlak konsistensi dalam penyelenggaraannya diintegrasikan dengan layanan Bina Keluarga Balita dan Posyandu bagi anak sejak lahir sampai dengan usia empat tahun tetapi juga dapat melayani anak hingga usia enam tahun yang pengelolaannya di bawah pembinaan pemerintah desa atau kelurahan.

\section{DAFTAR PUSTAKA}

Hariwijaya dan Bertani. 2009. PAUD Melejitkan Potensi Anak dengan Pendidikan Sejak Dini. Yogyakarta: Mahadika Publishing

Sanjaya, Wina. 2012. Perencanaan dan Desain Sistem Pembelajaran. Jakarta: Kencana

Sujiono, Yuliani Nurani. 2009. Konsep Dasar Pendidikan Anak Usia Dini. Jakarta: PT. Indeks

Departemen Pendidikan Nasional. 2010. Peraturan Menteri Pendidikan Nasional. Jakarta: Kementrian Pendidikan dan Kebudayaan Direktorat Jenderal Manajemen Pendidikan Dasar dan Menengah Direktorat Pembinaan TK dan SD.

Departemen Pendidikan Nasional. 2013. Petunjuk Teknis Penyelenggaraan Pos PAUD. Jakarta: Kementrian Pendidikan dan Kebudayaan Direktorat Jenderal Pendidikan Anak Usia Dini, Nonformal dan Informal Direktorat Pembinaan Pendidikan Anak Usia Dini.

Dinas Pendidikan. 2010. Rencana Program Pembelajaran (RPP) Pos PAUD Terpadu. Surabaya: Pemerintah Kota Surabaya

Martiyono. 2012. Perencanaan Pembelajaran. Yogyakarta: Aswaja Pressindo

Mukhtar, Latif dkk. 2013. Orientasi Baru Pendidikan Anak Usia Dini: Teori dan Aplikasi. Jakarta: KencanaPerdana Group

Direktorat Penelitian dan Pengabdian kepada Masyarakat, DIKTI, 2013. Panduan Pelaksanaan Penelitian Dan Pengabdian
JIP, Vol.7, No. 1, Edisi Januari 2017, Hal: 52-65

Rahayu Puji Suci, Suhermin, Triyonowati

Kepada Masyarakat Di Perguruan Tinggi Edisi IX.

Departemen Logistik Pemerintahan, (2012) "Membantu Anak Anda di Usia Taman Kanak-Kanak", Biro Pendidikan, Jakarta.

Dirjen PauD, Nonformal dan Informal, (2013), "Petunjuk Teknis Penyelenggaraan Taman Kanak-Kanak" Direktorat Pendidikan Usia Dini, Kementerian Pendidikan dan Kebudayaan.

Direktorat Pendidikan Anak Usia Dini, Pedoman Teknis Penyelenggaraan Kelompok Bermain, Jakarta: Direktorat Pendidikan Anak Usia Dini, Direktorat Jenderal Pendidikan Non Formal dan Informal, Kementerian Pendidikan Nasional, 2008.

Direktorat Pendidikan Anak Usia Dini, Pedoman Penyaluran Dana Bantuan Kelembagaan Pendidikan Anak Usia Dini, Jakarta: Direktorat Pendidikan Anak Usia Dini, Direktorat Jenderal Pendidikan Non Formal dan Informal, Kementerian Pendidikan Nasional, 2009.

Direktorat Pendidikan Anak Usia Dini, Pedoman Penyaluran Dana Bantuan Pengembangan Pusat Unggulan, Jakarta: Direktorat Pendidikan Anak Usia Dini, Direktorat Jenderal Pendidikan Non Formal dan Informal, Kementerian Pendidikan Nasional, 2009.

Direktorat Pendidikan Anak Usia Dini, Buletin PADU; Jurnal Ilmiah Anak Usia Dini, Jakarta: Direktorat Pendidikan Anak Usia Dini, Direktorat Jenderal Pendidikan Non Formal dan Informal, Kementerian Pendidikan Nasional, Desember 2008, Vol.7 No.3.

Slamet Suyanto, Dasar-dasar Pendidikan Anak Usia Dini, (Yogyakarta: Hikayat Publishing,2005

Undang-undang Republik Indonesia Nomor 23

Tahun 2002 Tentang Perlindungan Anak. 